\title{
Heavy and Light Chain Isotypes of Immunoglobulin in Epidermolysis Bullosa Acquisita
}

\author{
Ellen Mooney and W. Ray Gammon \\ Division of Dermatology, Faculty of Medicine, University of Iceland, Reykjavik, Iceland and Department of Dermatology, University of \\ North Carolina, Chapel Hill, North Carolina, U.S.A.
}

Epidermolysis bullosa acquisita (EBA) is a chronic acquired blistering disease with characteristic clinical, pathologic, and immunopathologic features. The disease is characterized immunopathologically by circulating and tissue-bound IgG class autoantibodies (EBA antibodies) to the basement membrane zone of stratified squamous epithelium. Previous studies have shown that circulating and tissue-bound EBA antibodies are heterogenous in their ability to activate complement and have raised the possibility that functional heterogeneity might be related to IgG subclass restriction. In this study, we have characterized the IgG subclasses of the circulating and tissue-bound EBA antibodies by immunofluorescence and have examined the relationship between IgG subclass and complement binding. The results show that EBA antibodies belonging to all IgG subclasses are present in the skin of EBA patients. The results also show that EBA antibodies belonging to all IgG subclasses are present in the sera of most patients, including sera with and without complement binding EBA antibodies. J Invest Dermatol 95:317319, 1990

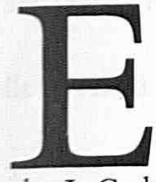
pidermolysis bullosa acquisita (EBA) is an uncommon, chronic, acquired subepidermal blistering disease characterized by circulating and tissue-bound autoantibodies to the basement membrane zone (BMZ) of stratified squamous epithelium. The antibodies belong mainly to the IgG class, bind on and just beneath the lamina densa, and react with type VII collagen, a matrix protein specific for basement membranes of stratified squamous epithelia.

Complement binding immunofluorescent studies have shown that circulating EBA antibodies consist of both complement binding and non-complement binding populations [2]. Evidence that tissue-bound EBA antibodies are also functionally heterogenous has been obtained from recent studies indicating that BMZ immune deposits in some EBA patients can activate complement and generate complement-derived mediators of inflammation, whereas in others they cannot [3]. One factor that could contribute to heterogeneity in the ability to activate complement is the subclass distribution of IgG EBA antibodies. Some subclasses, such as IgG1 and IgG3, are potent complement activators, whereas IgG2 and especially IgG4 are weak activators $[4,5]$.

To address this question, we have characterized the IgG subclasses of both circulating and tissue-bound EBA antibodies and have examined the relationship between subclass distribution and the ability of the antibodies to bind complement at the BMZ. In addition, we have characterized other classes of circulating and tissue-bound EBA antibodies.

Manuscript received September 8, 1989; accepted for publication April 2, 1990.

This work was presented at the Annual Meeting of the Society for Investigative Dermatology, May 5, 1987.

Reprint requests to: Ellen Mooney, M.D., Laknastofan Uppsölum, Kringlunni 8-12, IS 103 Reykjavík.

Abbreviations:

BMZ: basement membrane zone

EBA: epidemolysis bullosa acquisita

\section{MATERIALS AND METHODS}

Tissue and Sera Perilesional skin ( $3-4 \mathrm{~mm}$ punch biopsies) and sera were obtained from 10 EBA patients, and sera were obtained from an additional 13 patients. In all patients, EBA was diagnosed on the basis of previously published criteria [2]. Sera were aliquoted and stored at $-70^{\circ} \mathrm{C}$ until used. Biopsies were quick-frozen in liquid N2, mounted in OCT compound, and stored frozen at $-70^{\circ} \mathrm{C}$. Normal human skin used for immunofluorescence was immediately frozen in liquid N2 or first separated through the lamina lucida, as previously described [6], mounted in OCT compound, and then frozen. All dilutions of sera were made in $0.01 \mathrm{M}$ PBS. Fresh normal human serum was used as a source of complement.

Antibodies The following fluorescein isothiocyanate-conjugated (FITC) goat antibodies to human proteins were used: i) affinity purified anti-IgG (Cappel Labs, Cochranville, PA), ii) anti-IgD (heavy chain specific) (Cappel), iii) heavy chain specific anti-IgM (Kirkegaard \& Perry, Gaithersburg, MD.), iv) heavy chain specific anti-IgA (Kirkegaard \& Perry), v) anti-C3 (Cappel), vi) anti-lambda light chain (Cappel), and vii) anti-kappa light chain (Átlantic Antibodies, Scarborough, ME). The following murine monoclonal antibodies were used: 1) anti-human IgE (Hybritech, San Diego, CA), 2) IgG subclass specific antibodies for human $\operatorname{IgG} 1, \operatorname{IgG} 2, \operatorname{IgG} 3$, and IgG4 (Bionetics, Irving, TX), 3) IgA subclass specific antibodies for human IgA1 and IgA2 (gift from John F. Kearney, Ph.D., University of Alabama) [7]. FITC-conjugated sheep anti-mouse IgG antibody (species specific) was purchased from Cappel Labs.

ELISA Enzyme-linked immunosorbent assays (ELISA) of human myeloma proteins and purified IgG subclasses were used to determine the specificity of goat antibodies to human kappa and lambda light chains and murine monoclonal antibodies to IgG subclasses, respectively. The antibodies showed no cross reactivity at the following dilutions: IgG1 1:5000; IgG2 1:1500; IgG3 1:2000; IgG4 $1: 8000$; anti-lambda $1: 200$; and anti-kappa $1: 200$. 
Table I. Positive Staining of Heavy and Light Chains

\begin{tabular}{lccccccc}
\hline & $\operatorname{IgG}$ & $\operatorname{IgA}$ & $\operatorname{IgM}$ & $\operatorname{IgD}$ & $\operatorname{IgE}$ & $\mathrm{K}$ & $\lambda$ \\
\hline Biopsies & $10 / 10$ & $2 / 10$ & $5 / 10$ & $2 / 10$ & $5^{a} / 10$ & $10 / 10$ & $10 / 10$ \\
Sera & $21 / 23$ & $0 / 21$ & $3 / 21$ & $0 / 21$ & $\mathrm{ND}^{\mathrm{b}}$ & $18 / 19$ & $18 / 19$
\end{tabular}

a Weak positive staining

b ND, not done.

Immunofluorescence A standard direct immunofluorescence procedure was used to characterize $\operatorname{IgG}, \operatorname{Ig} A, \operatorname{IgD}$, kappa and lambda light chains, and C3 in EBA biopsies. Normal human skin was used as a negative substrate control in these studies. A two-step technique employing an initial unconjugated murine monoclonal antibody followed by a FITC-conjugated sheep antibody to murine $\operatorname{IgG}$ was used to characterize $\operatorname{IgE}, \operatorname{IgA} 1, \operatorname{IgA} 2, \operatorname{Ig} G 1, \operatorname{Ig} G 2, \operatorname{Ig} G 3$, and IgG4 deposits in EBA biopsies and serum EBA antibodies. Serum antibodies were assayed with $1.0 \mathrm{M} \mathrm{NaCl}$-separated normal human skin substrate as previously described [6]. Indirect C3-binding immunofluorescence was performed on $\mathrm{NaCl}$-separated skin as previously described [8].

Slides were examined under a Leitz Orthoplan fluorescence microscope. Intensity of specific immunofluorescence was graded on a scale of 0 (no staining) to $3+$ (intense staining). Trace staining was indicated when the staining was barely discernible but specific.

\section{RESULTS}

\section{Immunoreactants in EBA Biopsies}

Heavy and Light Chains: Perilesional skin specimens from 10 EBA patients were examined. All showed linear deposits of $\mathrm{IgG}$ at the BMZ. In addition, two specimens showed linear IgA, and another two, linear IgD deposits at the BMZ. Five biopsies had linear IgM at the BMZ, whereas five stained weakly for IgE along the BMZ. Two of these biopsies were positive for both $\operatorname{IgM}$ and $\mathrm{IgE}$. One of the patients with IgM deposits was rheumatoid factor positive. In all cases staining for immunoglobulin classes other than IgG was less intense than IgG staining. Linear deposits of kappa and lambda light chains were also seen in all biopsies, and we observed no difference in the staining intensity between these light chains (Table I).

Subclasses: Linear deposits of $\operatorname{IgG}$ subclass antibodies were seen in all EBA biopsies. Every biopsy contained at least two subclasses and most contained three or four subclasses. IgG1 was present in $80 \%$ of biopsies, IgG2 in 100\%, IgG3 in 70\%, and IgG4 in 100\% (Table II). Every biopsy contained IgG1, IgG3, or both. In the two biopsies

Table II. Tissue Bound IgG Subclasses

\begin{tabular}{ccccc}
\hline Patient & $\mathrm{IgG1}$ & $\mathrm{IgG} 2$ & $\mathrm{IgG} 3$ & $\mathrm{IgG} 4$ \\
\hline 1 & $1+$ & $2+$ & $1+$ & $2+$ \\
2 & - & $2+$ & - & $\operatorname{tr}^{a}$ \\
3 & $1+$ & $3+$ & - & $2+$ \\
4 & $1+$ & $2+$ & $1+$ & $3+$ \\
5 & $2+$ & $2+$ & $\operatorname{tr}$ & $3+$ \\
6 & $1+$ & $2+$ & $3+$ & $2+$ \\
7 & - & $3+$ & $1+$ & $3+$ \\
8 & $1+$ & tr & $1+$ & $\operatorname{tr}$ \\
9 & $1+$ & $1+$ & $\operatorname{tr}$ & $2+$ \\
10 & $80 \%$ & $100 \%$ & $70 \%$ & $100 \%$ \\
\hline
\end{tabular}

atr, trace.
Table III. Comparison of IgG Subclass and C3 Binding in Sera

\begin{tabular}{ccccccc}
\hline Patient & IgG1 & IgG2 & IgG3 & IgG4 & C3 Binding & Titer \\
\hline 1 & $1+$ & $2+$ & $2+$ & $3+$ & + & $1: 20$ \\
2 & $2+$ & $1+$ & $3+$ & $3+$ & + & $1: 20$ \\
3 & tr & tr & - & $2+$ & - & Na \\
4 & $1+$ & - & tr & - & + & \\
5 & tr & $2+$ & tr & $3+$ & - & \\
6 & $1+$ & $2+$ & $1+$ & $3+$ & - & $1: 40$ \\
7 & $2+$ & $2+$ & - & $3+$ & + & N \\
8 & tr & $1+$ & - & $2+$ & + & $1: 10$ \\
9 & tr & $3+$ & $1+$ & $1+$ & + & \\
10 & tr & $2+$ & - & $2+$ & - & \\
11 & $1+$ & tr & - & tr & + & $1: 5$ \\
12 & tr & tr & - & + & - & \\
13 & $1+$ & $2+$ & tr & $2+$ & - & \\
14 & tr & $2+$ & tr & $3+$ & - & \\
15 & $1+$ & tr & tr & $1+$ & + & \\
16 & tr & $2+$ & - & $3+$ & - & \\
17 & tr & $1+$ & - & tr & - & \\
18 & - & tr & - & tr & - & \\
Percent Positive & 94 & 94 & 50 & 94 & 44 & \\
\hline
\end{tabular}

a Neet or undiluted.

with $\operatorname{IgA}$ deposits, both stained with antisera for $\operatorname{IgA} 1$ and one stained for IgA2.

Complement: Linear deposits of $\mathrm{C} 3$ were present at the $\mathrm{BMZ}$ in all biopsies.

\section{Circulating Antibodies}

Heavy and Light Chains: IgG. EBA antibodies were detected in 21 of $23 \mathrm{EBA}$ sera indirect IgG immunofluorescence on $1.0 \mathrm{M} \mathrm{NaCl}$ separated skin. In addition, three of the sera had low titer IgM anti-BMZ antibodies that reacted with the substrate in a pattern indistinguishable from IgG EBA antibodies. One of these patients was rheumatoid factor positive. No other Ig class anti-BMZ antibodies were detected. Kappa and lambda light chain staining of approximately equal immunofluorescence intensity was observed at the BMZ in 18 of 19 sera tested.

Subclasses: The IgG subclasses of circulating EBA antibodies were characterized in 23 sera. IgG1 EBA antibody were present in $94 \%$ of those sera, IgG2 in 94\%, IgG3 in 50\%, and $\operatorname{IgG} 4$ in $94 \%$. IgG1, $\operatorname{IgG2}$, or both were present in all but one serum. An analysis of the prevalence of subclasses in corresponding sera and skin showed a $75 \%-88 \%$ concordance.

Complement Binding: Eight of 18 EBA sera were found to contain complement-binding EBA antibodies (Table III). We observed no significant correlation between the $\operatorname{IgG}$ subclass distribution of $\mathrm{EBA}$ antibodies and complement-binding. However, IgG1 and IgG3 subclasses did appear to be more intensely staining in complementbinding compared to non-complement-binding sera.

\section{DISCUSSION}

The results of this study confirm previous reports that circulating and tissue-bound EBA antibodies belong predominantly to the Ig $G$ class [2]. Evidence for EBA antibodies belonging to the IgA, IgM, and $\operatorname{IgE}$ classes has also been reported, and their presence was also confirmed in this study [9]. As in previous studies, we found that EBA antibodies belonging to classes other than IgG occur in the minority of patients. We also detected circulating IgM anti-BMZ antibodies that bound to separated normal human skin in a pattern identical to IgG EBA antibodies in three sera. To our knowledge, this is the first evidence of circulating EBA antibodies of a class other than IgG.

In addition to Ig heavy chains, we examined for kappa and lambda light chains in EBA antibodies and found that both types were present in all biopsies. This finding supports the evidence obtained 
from heavy chain analysis that EBA antibodies are polyclonal [3]. Our major objective in this study was to determine the IgG subclass distribution of EBA antibodies and examine the relationship of those subclasses and complement-binding EBA antibodies. Our results showed that both circulating and tissue-bound EBA antibodies in most patients contained multiple subclasses and that there is no clear relationship between complement deposition in vivo or circulating complement-binding and IgG subclass distribution. For that reason we conclude that the variability in functional activity of EBA antibodies is not due to IgG subclass distribution. These results are consistent with our view that variability in complement activation is more a function of amounts of complement activating subclasses than subclass distribution.

We would like to thank Robert Eisenberg, M.D., and Russel Hall, M.D., for supplying subclass antibodies and David Klapper, Ph.D., J. Charles Jennette, M.D., and Thorunn Rafnar, B.S. for technical advice.

\section{REFERENCES}

1. Woodley DT, Burgeson RE, Lunstrum G, Bruckner-Tuderman L, Reese MJ, Briggeman RA: Epidermolysis bullosa acquisita antigen is the globular carboxyl terminus of type VII procollagen. J Clin Invest $81: 683-687,1988$
2. Briggaman RA, Gammon WR, Woodley DT: Epidermolysis bullosa acquisita of the immunopathological type (dermolytic pemphigoid). J Invest Dermatol 85 (suppl):79S-84S, 1985

3. Gammon WR, Briggaman RA: Functional heterogeneity of immune complexes in epidermolysis bullosa acquisita. J Invest Dermatol 89:478-483, 1987

4. Puritz EM, Thompson JA, Dierberg JF, Kraus SJ, Yount WJ: IgG subclasses of fluorescent treponemal antibodies: correlation with complement fixation and clinical stage. Clin Immunol Immunopathol 4:352-362, 1975

5. Winkelhake JL: Immunoglobulin structure and effector functions. Immunochemistry 15:695-714, 1978

6. Gammon WR, Briggaman RA, Inman AO III, Queen LL, Wheeler CE: Differentiating anti-lamina lucida and anti-sublamina densa anti$\mathrm{BMZ}$ antibodies by indirect immunofluorescence on $1.0 \mathrm{M}$ sodium chloride-separated skin. J Invest Dermatol 82:139-144, 1984

7. Conley ME, Kearney JF, Lawton AR III, Cooper MD: Differentiation of human B cells expressing the IgA subclasses as demonstrated by monoclonal hybridoma antibodies. J Immunol 125:2311-2316, 1980

8. Carlo JR, Gammon WR, Sams WM Jr, Ruddy S: Demonstration of the complement regulating protein, $\mathrm{B} 1 \mathrm{H}$, in skin biopsies from patients with bullous pemphigoid. J Invest Dermatol 73:551 - 553, 1979

9. Fine JD, Tyring S, Gammon WR: The presence of intralamina lucida blister formation in epidermolysis bullosa acquisita: possible role of leukocytes. J Invest Dermatol 92:27-32, 1989 